\title{
一過性レジスタンス運動におけるアディポネクチン ,レプチンの応答
}

\begin{tabular}{|c|c|c|}
\hline 今井智子卢 & 相 澤 勝 治2) & 朱＼cjkstart美 賢3) \\
\hline 村井文江 ${ }^{4)}$ & 河 野一 郎 ${ }^{1)}$ & 今川重彦1) \\
\hline
\end{tabular}

\section{ACUTE EFFECTS OF RESISTANCE EXERCISE ON ADIPONECTIN AND LEPTIN}

\author{
Tomoko Imai, Katsuji Aizawa, Mi Hyun JoO, Kaoruko Iida, \\ Fumie Murai, ICHIRO Kono, SHigehiko Imagawa and Noboru MESAKI
}

\begin{abstract}
【Objective】 The purpose of this study was to investigate the acute responses of adiponectin and leptin to resistance exercise in healthy elderly men. 【Methods】 Eight healthy men (age, 25.5 \pm 3.3 yrs) participated in this study. They performed two trials. Trial 1 was an exercise session consisting of 5 resistance exercises at high-intensity ( $75 \%$ one-repetition maximum : 1 RM) with three sets of 10 repetitions. Trial 2 was a control trial at rest for the same time as trial 1 . Blood samples were taken to assess adiponectin, leptin, and metabolism related substances (glucose and lipids). 【Results】 Leptin significantly decreased $24 \mathrm{~h}$ after the resistance exercise but did not change in trial 2. Blood insulin and lactate concentrations significantly increased immediately $(0 \mathrm{~min})$ and 30 min after the exercise. However, adiponectin, glucose and lipids were not affected.

【Conclusion】 Adiponectin was not affected by resistance exercise, whereas leptin decreased $24 \mathrm{~h}$ after the exercise. This suggests that leptin may have quite a delayed response to high-intensity resistance exercise.
\end{abstract}

(Jpn. J. Phys. Fitness Sports Med. 2009, $58: 239 \sim 246$ )

key word : resistance exercise, adiponectin, leptin,

$$
\text { I . 緒言 }
$$

アディポネクチン , レプチンは脂肪細胞から分必 される生理活性物質で, 兴の総称はアディポサイト カインといわれている ${ }^{1,2)}$. 肥満者や糖尿病患者の アディポネクチンの濃度は低下し, 脂質代謝異常や 糖代謝異常のリスクが高まることが報告されてい

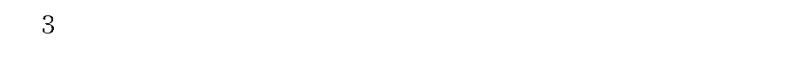
かけ，抗動脈硬化に作用することが明らかになって いる ${ }^{4)}$. 一方, レプチンは視床下部のレプチン受容 体に作用し，摂食や代謝調節に働いている1).レプ チンは, BMIや体脂肪率と正の相関がみられ, 肥満

1)筑波大学大学院人間総合科学研究科スポーツ医学専攻 干 305-8577 茨城県つくば市天王台1-1-1総合研究棟D616

${ }^{2)}$ 日本学術振興会特別研究員

=113-0033 東京都文京区本郷7-3-1

3) 全州大学校代替医学大学代替健康管理学部健康管理専攻 于560-759 韓国全州市完山区孝子洞3街1200

4)筑波大学大学院人間総合科学研究科看護科学専攻 干 305-8577 茨城県つくば市天王台1-1-1

5)帝京平成大学

干290-0192 千葉県市原市潤井戶2289
者はレプチンの過剩分泌がみられる5. 肥満による レプチン分泌の増加は高血圧, 動脈硬化症やインス リン抵抗性のリスクを高めることが報告されてい

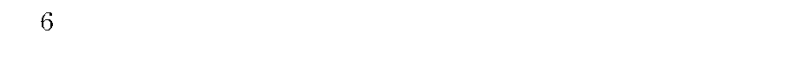
ンは，代謝機能の維持に重要な役割を果たしている と示唆されている.

$$
\text { アディポネクチン , レプチンは糖脂質代謝 }{ }^{1 \sim 31}
$$
の調節を行うため，レジスタンス運動やエアロビッ ク運動に対するアディポサイトカインの応答が複数 検討されている 7 田) . 長期間 , エアロビック運動 を用いてアディポサイトカインの応答を検討した報 告では, 脂肪量の減少が認められる場合にアディポ

Doctoral Program of Sports Medicine, Graduate School of Comprehensive Human Sciences, University of Tsukuba Research Fellow of the Japan Society for the Promotion of Science

Jeonju University College of Alternative Medicine School of Alternative Medicine \& Health Science

Nursing Science, Graduate School of Comprehensive Human Sciences, University of Tsukuba

Teikyo Heisei University 
ネクチンの増加 ${ }^{9)}$ やレプチンの減少 ${ }^{7)}$ が報告され， アディポサイトカインの応答には身体組成の変化が 必要であると考えられている．しかし，レジスタン ス運動とエアロビック運動ともに身体組成の変動が ない場合においてもアディポネクチンの増加 ${ }^{8,11)}$, レプチンの低下が報告されているため ${ }^{11)}$, アディ ポサイトカインは運動トレーニングにより変化する 可能性が考えられる.

レプチンの応答を確認した報告では, 長時間のエ アロビック運動において減少することを示す多くの

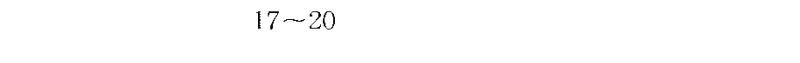
た場合にレプチンは減少すると考えられている .方，アディポネクチンは 変化しない ${ }^{12 \sim 15)}$ とする 報告が多いが, rowing 運動を用いた検討のみアデ イポンネクチンの増加を報告している ${ }^{16)}$. 同じ報 告においてレプチンも運動後, 短時間でレプチンの 減少を確認している .Jürimäeら ${ }^{16)}$ は全身の骨格筋 の70\%以上を使用し，無酸素性作業閾值 (anaerobic threshold) に達する運動 $\left(75.2 \pm 2.9 \% \dot{\mathrm{VO}}_{2 \max }\right)$ を 行ったことにより，アデイポサイトカインの応答を 認めた可能性を報告している .

これまで, アディポサイトカインの応答は有酸素 性エネルギー供給機構を主とするエアロビックな運 動を用いた報告が多く，無酸素性エネルギー供給機 構を主としたアネロビック運動においてアディポサ イトカインの応答を検討した報告は少ない．レジス タンス運動は骨格筋をダイナミックに収縮するアネ ロビック運動であり，Jürimäe ${ }^{16,21,22)}$ が用いた rowing 運動に類似した特徵がある．また，レジス タンス運動は糖をエネルギー源として使用するた め, アディポサイトカインの応答に影響する可能性 が示唆されている23).しかし，これまで,一般的 な一過性レジスタンス運動を用いて健常者のアディ ポサイトカインの応答を検討したものは少なく，ア ディポネクチンにおいては検討されていない，光こ で本研究は全身の大筋群を使用した一過性レジスタ ンス運動によりアディポサイトカインは応答すると いう仮説を設定し , アディポネクチン , レプチンの 応答を検討した。

$$
\text { II. 方法 }
$$

A. 対象者

対象者は, 日常生活において特別な運動習慣を持 たない健常男性 8 名 (25.5 3 3.3歳) を対象とした . 対象者の身体特性は表 1 に示した .これらの対象者 は喫煙習慣および特別な運動習慣はなかった .すべ ての対象者に研究の目的や手順, 途中で辞退できる ことを説明した上で, 文書による実験参加の同意を 得た .なお，本研究は筑波大学における「筑波大学 大学院人間総合科学研究科研究倫理委員会」の承認 を得て実施した .

Table 1. Physical characteristics of subjects $(n=8)$

\begin{tabular}{lrr}
\hline \multicolumn{1}{c}{ Variable } & & Mean \pm SD \\
\hline \hline Age & $(\mathrm{yr})$ & $25.5 \pm 3.3$ \\
Height & $(\mathrm{cm})$ & $176.5 \pm 3.0$ \\
Body mass & $(\mathrm{kg})$ & $68.8 \pm 4.0$ \\
Body fat & $(\mathrm{kg})$ & $11.1 \pm 3.6$ \\
\%Body fat & $(\%)$ & $16.0 \pm 4.6$ \\
Free fat mass & $(\mathrm{kg})$ & $57.7 \pm 2.9$ \\
BMI & & $22.0 \pm 0.9$ \\
\hline
\end{tabular}

Values are means \pm SD.

BMI, body mass index

\section{B. 実験スケジュール}

対照実験とレジスタンス運動は，1週間以上 2 週 間以内の間隔をおいて同じ時間帯で実施した . 対照 実験は運動を行わないで安静座位を保ち，レジスタ ンス運動と同樣に血液を採取した。また，対照実験 とレジスタンス運動の実施順序はランダム化した .

対象者には, 実験前日の運動, 飲酒を禁止し,さ らに夜 9 時以降に飲料水以外の食事およびカフェイ ンの摂取を行わないことを指示した . 対象者は最低 1 週間の期間をおいて 2 度の実験に協力した . 実験 期間中は生活習慣および食習慣を变化させないよう に指示した。

C. 最大挙上重量 ( 1 RM : one repetition maximum ）の測定

各運動種目 (ラットプルダウン , レッグカール , ベンチプレス , レッグエクステンション , スクワッ 
ト) の 1 RMは, 実際に使用するレジスタンスエク ササイズマシン (TOREDO,セノー株式会社, 東京) を用いて行った . 対象者は 1 RMの測定前に，正し いフォームの習得を行った . 1 RMの測定は 3 日前 より激しい運動を避けて行った . Trail and Error 方式（ある重量に対して 1 回挙上することができれ ば, さらに次の重量に臨むという方法) で行い，各 試技間の休息時間を 3 分〜 5 分とし，適切な動作規 定と動作範囲を維持するように指示した．また，最 初の重量は総試技数が 5 回を越えないように対象者 に決めさせた．なお，測定の間隔は十分に取り，対 象者の合図により進めた . 1 RM の判定は, 肘関節 あるいは膝関節が完全に伸展あるいは屈曲しなくな った時点の前の重量とした .

\section{D．レジスタンス運動}

実験の当日，対象者は空腹の状態で体重および身 体組成の測定を行った . 椅子にて安静を保った後， 採血を行い，弚の後ストレッチと準備運動として各 レジスタンス運動を 5 回ずつ行った (50％RM) . 運 動終了後は再び椅子に座り60分間の安静座位を保ち 続けた .

レジスタンス運動はラットプルダウン, レッグ カール, ベンチプレス , レッグエクステンション , スクワットによる5 種目の運動を行った . 運動強度 は事前に測定した $75 \%$ RM に負荷を調節した. 対象 者の $1 \mathrm{RM}$ と運動セッションで用いた負荷を表 2 に 示す. 反復動作速度は, 短縮性筋活動局面および伸 張性筋活動局面ともに 1 秒とし , メトロノームを用 いてリズムを合わせながら反復させた .なお，レジ スタンス運動は $75 \%$ RM の強度で10回 3 セット行 い, セット間の休息は 1 分間, 運動種目間の休息は
1 分間とした .

\section{E．測定方法}

血液検体はレジスタンス運動前, 運動終了直後， 運動30分後, 運動60分後, 運動24時間後に肘正中皮 静脈から $20 \mathrm{ml}$ の採血を行った．採取した血液は $4{ }^{\circ} \mathrm{C}, 3000$ 回転で，15分間遠心分離をした後，血清 分離をし，測定まで-40ㄷで凍結保存を行った．血 中の乳酸濃度は, 血液を採取した直後に血中乳酸測 定器 (Lactate Pro LT-1710, ARKRAY社, 京都)を用 いて測定した。

体重の測定には脂肪計付きへルスメータ (TBF-560, 株式会社タニタ, 東京) を用いた．脂肪 重量，除脂肪重量，体脂肪率，BMIの測定には多周 波インピーダンス機器（MLT-10，積水化学工業株 式会社，東京) を用いた。体重および身体組成の測 定は実験当日の測定前に行った .

アディポネクチンの濃度は測定キット (Human Adiponectin Immunoassay, ELISA kit, R \& D systems 社)を用い，ELISA法により測定を行った・レプ チンは RIA 法 (radioimmunoassay)，グルコースは 酵素法，インスリンは CLIA 法 (Chemiluminescent Immunoassay) を用いて分析した．遊離脂肪酸(FFA) はコレステロール脱水素酵素法, 総コレステロール (TC)，トリグリセリド(TG)，高比重リポ蛋白コレ ステロール(HDL-C)は酵素法にて測定を行った .

F. 統 計

全ての測定値は, 平均值 \pm 標準偏差で示した . 対照実験と運動群の条件間と時間経過に伴う平均値 の差は繰り返しのある二元配置分散分析法 (Twofactor factorial ANOVA) を行い，光の有意性を検

Table 2. Maximal strength, exercise load, and 1-repetition maximum $(n=8)$

\begin{tabular}{lcc}
\hline Exercise & 1RM $(\mathrm{kg})$ & Exercise load $(\mathrm{kg})$ \\
\hline \hline Lat pull down & $56.1 \pm 14.7$ & $44.4 \pm 10.4$ \\
Bench press & $58.6 \pm 11.4$ & $44.4 \pm 8.6$ \\
Leg curl & $49.7 \pm 9.9$ & $39.0 \pm 7.6$ \\
Leg extension & $67.4 \pm 6.1$ & $54.6 \pm 4.7$ \\
Squat & $128.8 \pm 23.0$ & $100.0 \pm 16.9$ \\
\hline
\end{tabular}

Values are means $\pm \mathrm{SD}$ 
討した · 交互作用がない場合は各条件について多重 比較検定を行った（Tukey-Kramer）. 二元配置分散 分析で交互作用に有意差がみられた項目は 2 要因の すべての組み合わせを多重比較検定 (Tukey-Kramer) を用いて検討した .すべての統計処理は統計ソフト Stat View 5.0 日本語版を用い, 有意水準は $5 \%$ 末 満とした。

III. 結果

レプチンは運動群と対照群に, 交互作用はなく， 各々の経時的変化を検討した . 弚の結果, 対照群は 介入前に対し介入 60 分後に有意な低下が認められ た．運動群は運動前に対し運動60分後と運動24時間 後に有意な低下が認められた (図 1 ) . アディポネ クチンは条件間, 時間経過ともに変化は認められな かった (図 2 ).

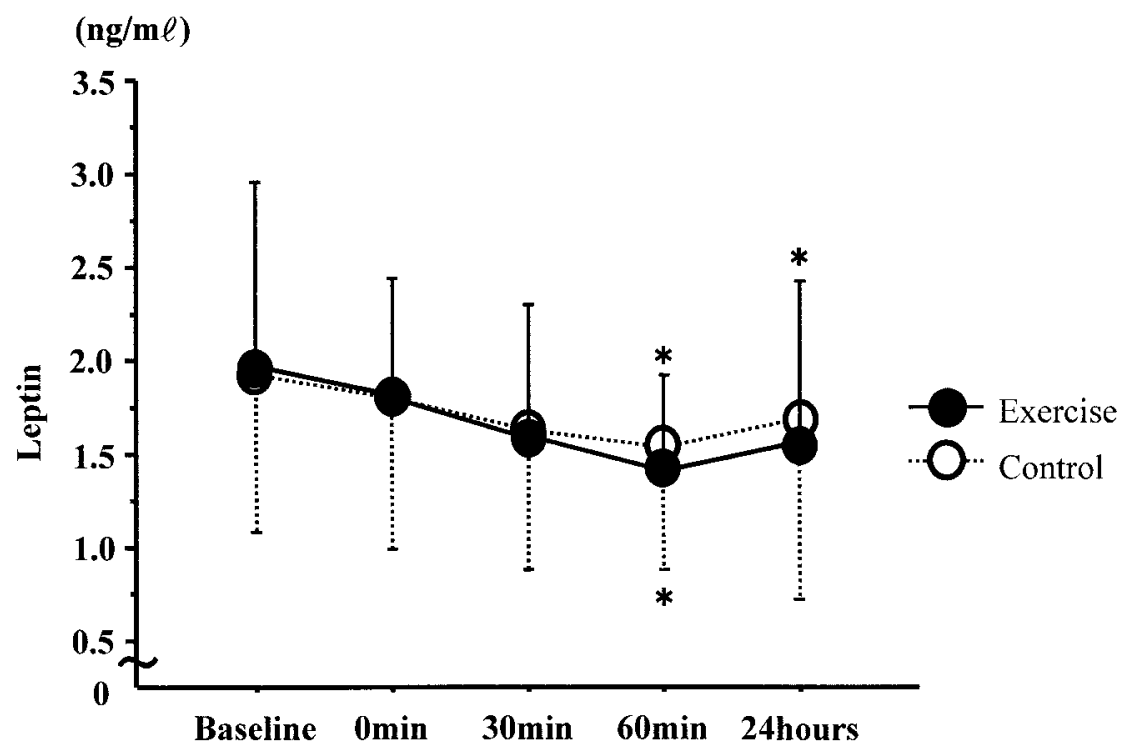

Fig. 1. The acute effect of resistance exercise on serum leptin concentration $(n=8)$ Values are means $\pm \mathrm{SD}$.

$*_{\mathrm{p}}<0.05$ ( vs. Baseline )

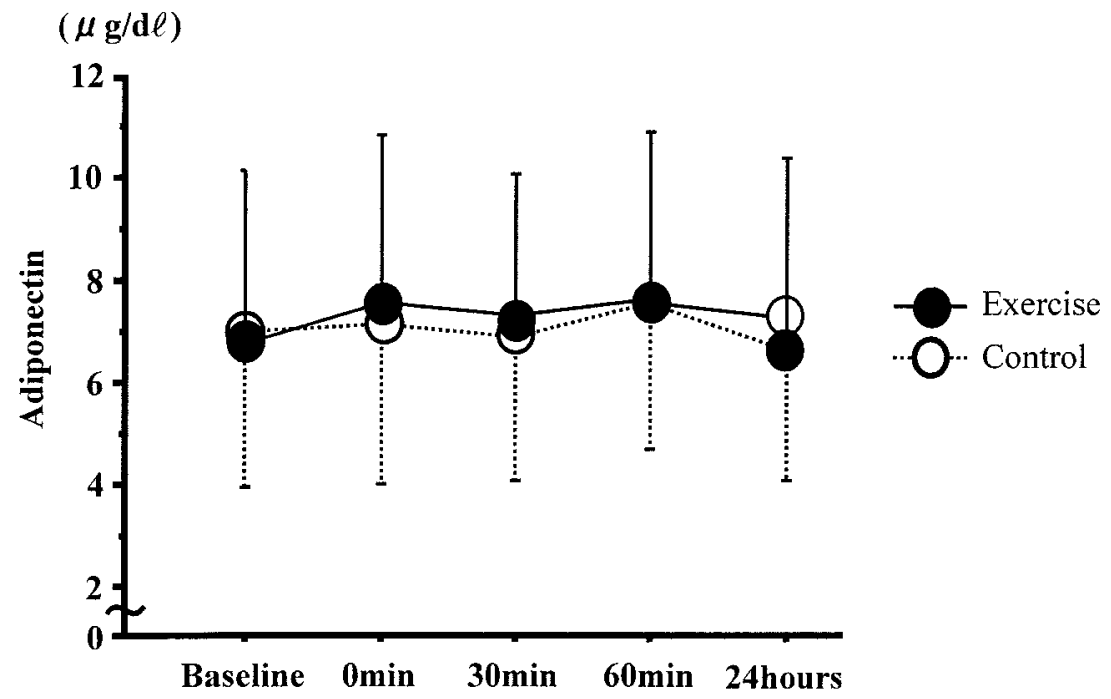

Fig. 2. The acute effect of resistance exercise on serum adiponectin $(n=8)$ Values are means $\pm \mathrm{SD}$. 
Table 3. The acute effects of resistance exercise on serum parameters $(n=8)$

\begin{tabular}{|c|c|c|c|c|c|}
\hline & Baseline & $0 \mathrm{~min}$ & $30 \mathrm{~min}$ & $60 \mathrm{~min}$ & 24hours \\
\hline Glucose & $(\mathrm{mg} / \mathrm{d} \ell)$ & & & & \\
\hline $\mathbf{E x}$ & $85.9 \pm 2.6$ & $87.5 \pm 2.4$ & $93.5 \pm 12.7$ & $82.0 \pm 4.4$ & $85.9 \pm 3.3$ \\
\hline Co & $87.3 \pm 5.2$ & $87.0 \pm 5.3$ & $87.0 \pm 5.6$ & $85.9 \pm 7.1$ & $89.4 \pm 6.3$ \\
\hline Insulin & $(\mathbf{m c u} / \mathbf{m} \ell)$ & & & & \\
\hline $\mathbf{E x}$ & $6.2 \pm 1.9$ & $11.5 \pm 3.3^{*}$ & $13.4 \pm 3.4^{*}$ & $7.8 \pm 3.2$ & $4.7 \pm 1.5$ \\
\hline Co & $6.4 \pm 1.9$ & $6.3 \pm 2.3$ & $6.1 \pm 1.8$ & $5.4 \pm 2.2$ & $4.7 \pm 1.1$ \\
\hline Lactate & $(\mathrm{mmol} / \ell)$ & & & & \\
\hline $\mathbf{E x}$ & $1.4 \pm 0.7$ & $11.5 \pm 1.2^{*} *$ & $6.0 \pm 0.7^{*} \ddagger$ & $2.8 \pm 0.6^{*} \ddagger$ & $1.2 \pm 0.3$ \\
\hline Co & $1.3 \pm 0.4$ & $1.2 \pm 0.2$ & $1.2 \pm 0.3$ & $1.1 \pm 0.4$ & $1.3 \pm 0.4$ \\
\hline FFA & $(\mathbf{m E q} / \ell)$ & & & & \\
\hline $\mathbf{E x}$ & $0.4 \pm 0.2$ & $0.2 \pm 0.0$ & $0.4 \pm 0.4$ & $0.2 \pm 0.1$ & $0.4 \pm 0.2$ \\
\hline Co & $0.4 \pm 0.2$ & $0.3 \pm 0.1$ & $0.3 \pm 0.1$ & $0.3 \pm 0.1$ & $0.4 \pm 0.2$ \\
\hline TG & $(\mathbf{m g} / \mathbf{d} \ell)$ & & & & \\
\hline $\mathbf{E x}$ & $78.9 \pm 30.3$ & $91.4 \pm 33.0$ & $71.4 \pm 27.8$ & $70.1 \pm 27.1$ & $77.5 \pm 33.2$ \\
\hline Co & $68.8 \pm 28.8$ & $67.4 \pm 26.7$ & $68.8 \pm 26.6$ & $68.4 \pm 27.3$ & $75.0 \pm 34.6$ \\
\hline TC & $(\mathrm{mg} / \mathrm{d} \ell)$ & & & & \\
\hline $\mathbf{E x}$ & $167.1 \pm 16.5$ & $190.0 \pm 18.2$ & $168.4 \pm 17.21$ & $166.5 \pm 18.2$ & $171.3 \pm 18.4$ \\
\hline Co & $172.8 \pm 18.1$ & $169.3 \pm 15.3$ & $172.5 \pm 17.01$ & $173.9 \pm 18.1$ & $171.4 \pm 18.7$ \\
\hline HDL-C & $(\mathrm{mg} / \mathrm{d} \ell)$ & & & & \\
\hline $\mathbf{E x}$ & $54.6 \pm 10.1$ & $63.8 \pm 12.9$ & $56.3 \pm 11.8$ & $54.9 \pm 10.6$ & $58.3 \pm 11.4$ \\
\hline Co & $56.6 \pm 11.0$ & $55.5 \pm 10.4$ & $56.4 \pm 10.4$ & $57.1 \pm 11.5$ & $57.4 \pm 9.8$ \\
\hline
\end{tabular}

Values are means $\pm \mathrm{SD}$.

$* \mathrm{p}<0.05$ (vs. Baseline)

$\pm \mathrm{p}<0.05$ (vs. Control)

FFA: Free fatty acids

TG: Triglyceride

TC: Total cholesterol

HDL-C: High density lipoprotein cholesterol

Ex: Exercise, Co:Control

血糖，インスリン, 乳酸は交互作用か認められた ので条件間および時間経過の検討を行った (表 3 ). 产の結果, 運動群の血糖は運動前に対し有意な变化 は認められなかった . また, 運動群と対照群の血糖 值の変化も認められなかった . 運動群のインスリン は運動前および対照群に対し運動後, 運動30分後に 有意な増加がみられた . 運動群の乳酸は運動前およ び対照群に対し運動後, 運動30分後, 運動60分後に 有意な増加か認められた . 対照群の血糖 , インスリ ン 乳酸の時間経過による応答は認められなかった . 運動群, 対照群ともにFFA, TC, TG, HDL-C
は条件間, 時間経過ともに変化は認められなかっ た.

$$
\text { N. 考察 }
$$

本研究では, 一般男性を対象に高強度レジスタン ス運動にてアディポネクチンとレプチンの応答を検 討したところ, 運動群のレプチンは 24 時間後に低下 したが , アディポネクチンには明らかな変化は認め られなかった，全身の大筋群を用いた一過性レジス タンス運動は, 運動後に血中のレプチンの濃度を低 下させることが示された . 
レプチンは日内変動や絶食の影響により変動する ことが明らかになっている．また，レプチンは消費 したエネルギー量が多い場合 (800kcal以上) や筋 グリコーゲンの減少 ${ }^{24)}$, 乳酸による骨格筋の糖利 用の増加 ${ }^{25)}$ ，アシドーシス ${ }^{26)}$ により低下すること が明らかになっている．しかしながら，エアロビッ ク運動 ${ }^{27)}$ ，レジスタンス運動 ${ }^{28)}$ の報告ではエネル ギー消費量の多い運動以外はレプチンの減少を報告 していない，一方，Jürimäe らはこれまでの報告と 異なり, 短時間の rowing 運動 (30分) で運動直後 にレプチンの低下を報告している ${ }^{16,22)}$. 本研究に 類似したプロトコルを用いた報告では総消費エネル ギーは約300kcalであったとされている ${ }^{29)}$.したがっ て, 本研究の総消費エネルギーは800kcal以下であ ることが推測でき, レプチンの低下はエネルギー消 費量に依存した低下ではない可能性が示唆される． 本研究は運動後, 乳酸は明らかな増加を示した . 高強度レジスタンス運動を行った結果, 運動直後の 乳酸值は運動前の約 10 倍になり，筋中のグリコーゲ ンが多く消費された可能性がある ${ }^{24,30)}$. 高強度レ ジスタンス運動による骨格筋のグリコーゲンの消費 の増加や六進, GLUT 4 発現の増加( ${ }^{31)}$ 相対的に 脂肪細胞での糖の取り込みや利用を減少させた可能 性がある.ラットの脂肪細胞ではグルコース輸送体 または糖新生を制限することにより，レプチンが低 下することが報告されている ${ }^{32)}$. したがって，レ ジスタンス運動は脂肪細胞での糖の取り込みや利用 を減らし,レプチンを低下させた可能性がある 23,29).

レプチンはこれまで, 運動直後ではなく，24〜 48 時間後に応答が確認されている. Nindlら ${ }^{28)}$ は, 過 剩な量のレジスタンス運動を行わせることによって 9 １3時間後にレプチンの低下がみられたことを報 告している.エアロビック運動の報告も24〜48時間 後にレプチンの減少を報告している ${ }^{19,27)}$. 本研究 ではこれまでの報告と同樣に遅延してレプチンの低 下を認めた .レプチンの応答が遅延することに関し ては明確な知見は得られていないが, 脂肪細胞の Ob 遺伝子発現には時間を要するためレプチンの応 答が遅延すると考えられている23,32). 光の他, レ ジスタンス運動により産生されるホルモンや代謝産 物が運動による影響と拮抗するためレプチンの応答 が遅延する可能性が考えられている ${ }^{29)}$. 本研究で
は血糖の明らかな増加は認められていないが, 運動 直後にわずかに増加している．また，本研究では検 討を行っていないが，レジスタンス運動後は血中の アドレナリン, ノルアドレナリン ${ }^{33)}$, 成長ホルモ ン $(\mathrm{GH})^{34)}$ やコルチゾル ${ }^{29)}$ が増加することが報告 されている．アドレナリン，ノルアドレナリンは レプチンの分泌を抑制し，GHやコルチゾルはレプ チンの分泌 ${ }^{27)}$ を刺激するため, レジスタンス運動 後に産生された代謝産物がレプチンの応答と拮抗 し，応答が遅延した可能性がある ${ }^{29)}$.

上肢, 下肢の大筋群を用いた高強度レジスタンス 運動により,アディポネクチンの増加を期待したが， 明らかな変化は認められなかった . 本研究では, 運 動後にインスリンの分泌か増加している . インスリ ンはアディポネクチンの分必を抑制する゙)ため，ア ディポネクチンの応答がみられなかった可能性があ る、しかしながら，エアロビック運動後のインスリ ンの低下は, アディポネクチンの応答に影響しない 15) という報告がみられる。したがって，一過性の 運動によるインスリンの応答はアディポネクチンに 影響を与えていない可能性もある.ただし, 運動時 の血中のインスリン分泌の増加が脂肪細胞のアディ ポネクチンの合成に影響するかは明確になっていな いため, 運動時の血中のインスリン動態とアディポ ネクチンとの関連については検討していく必要があ る.さらに，レジスタンス運動後は多くの代謝産物 が産生される ${ }^{29)}$. 骨格筋から分泌される TNF- $\alpha^{35)}$ や IL-6 ${ }^{36)}$ の炎症性サイトカインや男性ホルモン ${ }^{37)}$ はレジスタンス運動後に増加する .これらは, アデ イポネクチンの産生を抑制するため ${ }^{38)}$ 運動による アディポネクチンの応答に影響した可能性がある .

脂質代謝とアディポネクチン , レプチンの関連に ついて検討を行ったが，FFA，TC，TG，HDL-Cの 変化は認められなかった FFA はPアディポサイト カインの分泌に影響を与えることが報告されてい る ${ }^{10)}$.しかしながら，レジスタンス運動を用いて FFAの応答を検討した報告では本研究と同樣に FFAの応答を認めてない ${ }^{15)}$. FFA はレジスタンス 運動によるアディポサイトカインの応答には関係し ていない可能性がある．ただし，レジスタンス運動 後に脂肪細胞のトリアシルグリセロールリパーゼの 活性, 血清グリセロールの増加 ${ }^{39}$ )骨格筋の脂質減 少 $^{30)}$ が報告されているため, 筋や脂肪細胞におい 
て何らかの影響がみられた可能性はあるが, 本研究 では明らかに出来なかった 。

これまでの報告では, 運動によりアディポネクチ ンに影響がみられた報告は限られているが，レジス タンス運動を用いた検討は少ない、レジスタンス運 動は運動種目, 強度, 回数により代謝産物の応答が 異なるため, 異なる運動方法を用いてレジスタンス 運動におけるアディポネクチンの影響について検討 していくことが必要である.

\section{И.ま と め}

本研究は一過性高強度レジスタンス運動がアディ ポネクチン,レプチンに及ぼす影響を検討した . 結 果，運動群と対照群ではレプチンの応答時間に違い か認められ，24時間後は運動群のみレプチンの低下 が認められた . 全身の大筋群を用いた一過性レジス タンス運動はレプチンを低下させるが, 兴の応答は 24時間後にみられることか明らかになった .

(受理日 平成21年 1 月 7 日)

\section{文献}

1) Minokoshi, Y., Kim, Y. B., Peroni, O. D., Fryer, L. G., Müller, C., Carling, D., Kahn, B.B. Leptin stimulates fatty-acid oxidation by activating $\mathrm{AMP}-$ activated protein kinase. Nature.,(2002), 415, 339-343.

2) Yamauchi, T., Kamon, J., Minokoshi, Y., Ito, Y., Waki, H., Uchida, S., Yamashita, S., Noda, M., Kita, S., Ueki, K., Eto, K., Akanuma, Y., Froguel, P., Foufelle, F. Ferre, P., Carling, D., Kimura,S., Nagai, R., Kahn, B. B., Kadowaki, T. Adiponectin stimulates glucose utilization and fatty-ac-cid oxidation by activating AMP-activated protein kinase., Nat. Med., (2002), 8, 1288-1295.

3) Cnop, M., Havel, P.J., Utzschneider, K.M., Carr, D.B., Sinha, M.K., Boyko, E.J., Retzlaff, B. M., Knopp, R. H., Brunzell, J. D., Kahn, S. E. Relationship of adiponectin to body fat distribution,insulin sensitivity and plasma lipoproteins: evidence for independent roles of age and sex. Diabetologia., (2003), 46, 459-469.

4) Goldstein, B. J., Scalia, R. J. Adiponectin: A novel adipokine linking adipocytes and vascular function. Clin. Endocrinol Metab. (2004), 89, 2563-2568.

5) Wannamethee, S.G., Tchernova, J., Whincup, P., Lowe, G.D., Kelly, A., Rumley, A., Wallace, A. M., Sattar, N. Plasma leptin: associations with metabolic, inflammatory and haemostatic risk factors for cardiovascular disease. Atherosclerosis.,(2007),191, 418-426.

6) Aizawa-Abe, M., Ogawa, Y., Masuzaki, H., Ebihara,
K., Satoh, N., Iwai, H., Matuoka, N, Hayashi,T., Hosoda,K., Inoue,G., Yoshimasa,Y,. Nakao,K. Pathophysiological role of leptin in obesity-related hypertension., J. Clin. Invest.(2000), 105, 1243-1252.

7) Pollock, M.L., Franklin, B.A., Balady, G..J., Chaitman, B.L., Fleg, J.L., Fletcher, B., Limacher, M., Piña, I.L., Stein, R.A., Williams, M., Bazzarre, T. Acute and chronic effects of exercise on leptin levels in humans., J. Appl. Physiol.,(1997), 83, 5-10.

8) Kriketos, A.D., Gan, S.K., Poynten, A. M., Furler, S. M., Chisholm, D. J., Campbell, L. V., Exercise increases adiponectin levels and insulin sensitivity in humans. Diabetes Care.,(2004), 27, 629-630.

9) Hulver, M.W, Zheng, D., Tanner, C.J., Houmard, J.A., Kraus, W.E., Slentz, C.A., Sinha, M.K., Pories, W.J., MacDonald, K.G., Dohm, G.L. Adiponectin is not altered with exercise training despite enhanced insulin action. Am. J. Physiol. Endocrinol Metab., (2002), 283, 861-865.

10) Berggren, J. R., Hulver, M. W., Houmard, J. A. Fat as an endocrine organ: influence of exercise. J. Appl. Physiol., (2005), 99, 757-764.

11) Fatouros, I.G., Tournis, S., Leontsini, D., Jamurtas, A.Z., Sxina, M., Thomakos, P., Manousaki, M., Douroudos, I., Taxildaris, K., Mitrakou, A. Leptin and adiponectin responses in overweight inactive elderly following resistance training and detraining are intensity related. J. Clin. Endocrinol. Metab., (2005), 90, 5970-5977.

12) Kraemer, R.R., Aboudehen, K.S., Carruth, A.K., Durand, R.T., Acevedo, E.O., Hebert, E. P., Johnson, L. G., Castracane, V. D. Adiponectin responses to continuous and progressively intense intermittent exercise. Med. Sci. Sports. Exerc., (2003), 35, 1320-1325.

13) Ferguson, M.A., White, L. J., McCoy, S., Kim, H.W., Petty, T., Wilsey, J. Plasma adiponectin response to acute exercise in healthy subjects. Eur. J. Appl. Physiol., (2004), 91, 324-329.

14) Jamurtas, A. Z., Theocharis, V., Koukoulis, G., Stakias, N., Fatouros, I.G., Kouretas, D., Koutedakis, Y. The effects of acute exercise on serum adiponectin and resistin levels and their relation to insulin sensitivity in overweight males. Eur. J. Appl. Physiol.,(2006), 97, 122-126.

15) Numao. S., Suzuki, M., Matsuo, T., Nomata, Y., Nakata, Y., Tanaka, K. Effects of acute aerobic exercise on high-molecular-weight adiponectin. Med. Sci. Sports Exerc., (2008), 40, 1271-1276.

16) Jürimåe, J., Hofmann, P., Jürimäe, T., Mảestu, J., Purge, P., Wonisch, M., Pokan, R., Duvillard, S.P. Plasma adiponectin response to sculling exercise at individual anaerobic threshold in college level male rowers. Int. J. Sports Med.,(2006), 27, 272-277.

17 ) Landt. M., Lawson, G.M., Helgeson, J.M., Davila-Roman, V.G., Ladenson, J.H., Jaffe, A.S., Hickner, R.C. Pro- 
longed exercise decreases serum leptin concentrations. Metabolism.,(1997), 46, 1109-1112.

18) Leal-Cerro, A., Garcia-Luna, P.P., Astorga, R., Parejo, J., Peino, R., Dieguez, C., Casanueva, F.F. Serum leptin levels in male marathon athletes before and after the marathon run. J. Clin. Endocrinol Metab.,(1998), 83, 2376-2379.

19) Olive, J. L., Miller, G. D. Differential effects of maximal-and moderate-intensity runs on plasma leptin in healthy trained subjects. Nutrition., (2001), 17, 365-369.

20) Zaccaria, M., Ermolao, A., Roi, G.S., Englaro, P., Tegon, G., Varnier, M. Leptin reduction after endurance races differing in duration and energy expenditure. Eur. J. Appl. Physiol.,(2002), 87, 108-111.

21) Jürimảe, J., Purge, P., Jürimåe,T. Adiponectin is altered after maximal exercise in highly trained male rowers. Eur. J. Appl. Physiol., (2005), 93, 502-505.

22) Jürimảe, J., Jürimåe, T. Leptin responses to short term exercise in college level male rowers. Br. J. Sports Med.,(2005), 39, 6-9.

23) Kanaley, J. A., Fenicchia, L. M., Miller, C. S., PloutzSynder, L.L., Weinstock, R. S., Carhart, R., Azevedo, J. L. Jr. Resting leptin responses to acute and chronic resistance training in type 2 diabetic men and women. Int. J. Obes. Relat. Metab. Disord.,(2001), 25, 1474-1480.

24) MacDougall, J. D., Ray, S,. Sale, D. G., McCartney, N., Lee, P., Garner, S. Muscle substrate utilization and lactate production. Can. J. Appl. Physiol.,(1999), 24, 209-215.

25) Mueller, W.M., Stanhope, K.L., Gregoire, F., Evans, J.L., Havel, P.J. Effects of metformin and vanadium on leptin secretion from cultured rat adipocytes. Obes. Res., (2000), 8, 530-539.

26) Teta, D., Bevington, A., Brown, J., Throssell, D., Harris, K. P., Walls, J. Effects of acidosis on leptin secretion from 3T3-L1 adipocytes and on serum leptin in the uraemic rat. Clin. Sci. (Lond). (1999), 97, 363-368.

27) Essig, D. A., Alderson, N. L., Ferguson, M. A., Bartoli, W. P., Durstine, J. L. Delayed effects of exercise on the plasma leptin concentration. Metabolism., (2000),49, 395-399.

28) Nindl, B. C., Kraemer, W. J., Arciero, P. J., Samatallee, N., Leone, C.D., Mayo, M.F., Hafeman, D. L. Leptin concentrations experience a delayed reduction after resistance exercise in men. Med. Sci. Sports Exerc. (2002) 34. 608-613.

29) Zafeiridis, A., Smilios, I., Considine, R. V., Tokmakidis, S. P. Serum leptin responses after acute resistance ex- ercise protocols. J. Appl. Physiol.,(2003), 94, 591-597.

30) Koopman, R., Manders, R. J., Jonkers, R. A., Hul, G. B., Kuipers, H., van Loon, L. J. Intramyocellular lipid and glycogen content are reduced following resistance exercise in untrained healthy males. Eur. J. Appl. Phy siol.,(2006), 96, 525-534.

31) Pereira, L. O., Lancha, A. H. Jr. Effect of insulin and contraction up on glucose transport in skeletal muscle. Prog. Biophys. Mol. Biol.(2004), 84, 1-27.

32) Mueller, W. M., Gregoire, F. M., Stanhope, K.L., Mobbs, C.V, Mizuno, T. M., Warden, C. H., Stern, J. S., Havel, P. J. Evidence that glucose metabolism regulates leptin secretion from cultured rat adipocytes. Endocrinology. (1998), 139, 551-558.

33) Kraemer, W. J., Ratamess, N. A. Hormonal responses and adaptations to resistance exercise and training. Sports Med.(2005), 35, 339-361.

34) Volek, J. S., Kraemer, W. J., Bush, J. A., Incledon, T., Boetes M. Testosterone and cortisol in relationship to dietary nutrients and resistance exercise. J. Appl. Physiol.(1997), 82, 49-54.

$35)$ Saghizadeh, M., Ong, J. M., Garvey, W.T., Henry, R. R., Kern, P. A. The expression of TNF alpha by human muscle. Relationship to insulin resistance. J. Clin. Invest.,(1996), 97, 1111-1116.

36) Fasshauer, M., Kralisch, S., Klier, M., Lossner, U., Bluher, M., Klein, J., Paschke, R. Adiponectin gene expression and secretion is inhibited by interleukin 6 in 3T3-L1 adipocytes. Biochem Biophys Res. Commun., (2003), 301, 1045-1050.

37) Häkkinen, K., Pakarinen, A., Kraemer, W. J., Newton, R. U., Alen, M., Basal concentrations and acute responses of serum hormones and strength development during heavy resistance training in middle-aged and elderly men and women. J. Gerontol. A. Biol. Sci. Med. Sci. (2000), 55, 95-105.

38) Combs, T. P., Berg, A. H., Rajala, M. W., Klebanov, S., Iyengar, P., Jimenez-Chillaron J. C., Patti, M. E., Klein, S. L., Weinstein, R. S., Scherer, P. E. Sexual differentiation, pregnancy, calorie restriction, and aging affect the adipocyte-specific secretory protein adiponectin. Diabetes.,(2003), 52, 268-276.

$39)$ Chatzinikolaou, A., Fatouros, I., Petridou, A., Jamurtas, A., Avloniti, A., Douroudos, I., Mastorakos, G., Lazaropoulou, C., Papassotiriou, I., Tournis, S., Mitrakou, A., Mougios, V. Adipose tissue lipolysis is upregulated in lean and obese men during acute resistance exercise. Diabetes, Care.(2008), 31, 1397-1399. 